\title{
The Genus Callitriche (Callitrichaceae) in Asia
}

\author{
Richard V. Lansdown
}

45 The Bridle, Stroud, Glos, GL5 4SQ, United Kingdom. rlansdown@ardeola.demon.co.uk

Abstract. Taxonomic review is provided for Callitriche taxa occurring in central and eastern Asia east of the Urals and in southeastern Asia north of Irian Jaya Barat. Three new species: Callitriche fuscicarpa. C. glareosa, and C. raveniana are described from Nepal, Bhutan, and Taiwan, China, respectively. Two new varieties are also described: Callitriche palustris L. var. megalala from Siberia in Russia and Callitriche palustris L. var. strumosa from westem Sumatra in Indonesia. Callitriche nana is newly referred as a synonym of $C$. japonica Engelmann ex Hegelmaier. Callitriche oryzetorum Petrov is transferred and reduced in rank to a variety of C. palustris L. Callitriche wightiana Wallich in Wight is lectotypified.

Key words: Asia, Callitriche, Callitrichaceae.

Callitriche L. is a genus of monoecious, or in a single case (C. petriei R. Mason subsp. petriei), dioecious, plants, with flowers that are axillary and usually solitary but that may occur in various combinations in the same axil; the perianth is absent but a subtending pair of bracts may be present in some species. The fruits are schizocarps, separating into four mericarps, which are dry, winged or not, with wings from the inner fruit layer. The taxonomy and identification of Callitriche species are dependent almost entirely on reproductive features, although occasionally other details such as venation and leaf shape may also be useful.

In preparing the treatment of Callitriche for the English version of the Flora of China series, herbarium specimens were studied from an area in Asia extending from the Urals east to Kamchatka and Ussuriland in the Russian Far East and south to southern Indonesia but excluding the eastern province of Irian Jaya Barat. Populations from here and Papua New Guinea were excluded as they appear to have closer affinities with Australasian taxa of the genus (Merrill \& Perry, 1941; Schotsman, 1985).

Three new species were identified: Callitriche fuscicarpa occurring in the Himalayas, from India through Nepal to southern China; C. glareosa represented by single specimens from Bhutan and Tibet; and C. raveniana apparently only occurring in Taiwan. Callitriche palustris L. was found to show strong variation, with extremes being described as var. megalata from Kanchatka in Russia, var. strumosa from islands in southeastern Asia, and var. oryzetorum, formerly described as C. oryzetorum Petrov, from southern China, Japan, and Taiwan.

Few accounts of the genus in Asia give due consideration to reproductive features and consequently there is much misidentification. Many accounts report Callitriche stagnalis Scopoli from Asia (Cheng \& Ming, 1980; Kak \& Javeid, 1982; Cook, 1996; Sarwar, 1998; Larsen, 2000), while Kak and Javeid (1982) also report C. obtusangula Le Gall and $C$. truncata Gussone. However, thorough review of herbarium material (Schotsman, 1985; Lansdown, 2006 , in press) has failed to find any material of $C$. stagnalis east of the Urals, C. obtusangula east of the Mediterranean, or C. truncala east of the Black Sea. When possible, I have taken the literature into account in preparing this revision. However, problems with potential misidentification mean that the literature has mainly been used to clarify elements of distribution.

The information employed to prepare this revision derives from review of more than 400 specimens in BM, CGE, E, HAST, HIB, K, L, LE, MICH, MO, P, PE, PPI, TAI, TNM, and TNU. All descriptive and biometric data employed here are based on herbarium specimens collected in Asia, except for those relating to C. palustris var. palustris. The list of material studied indicales the number of specimens seen; however, where data were collected from only a small number of specimens, this is stated.

I have provided illustrations of the fruits of each taxon except where these are already available in the literature. I have provided a key to the identification of all taxa known to occur in the region, although only novelties are considered in the text.

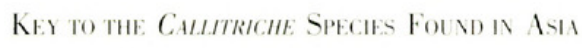

Ia. Fruits unwinged . . . . . . . . . . . . . . . . . .

1b. Fruils clearly winged . . . . . . . . . . . 5

2a. Bracts lacking ........... . peploides Nultall

2b. Bracts present .......................

3a. NIl leaves lingulate with only a single vein; bracts caducous ................ subanceps Petros

3b. Some or all leaves expanded, 1- to many-veined; bracts persistent . . . . . . . . . . . . 4

4a. Bracts as long and wide as ripe fruil; leaf venation simple. . . . . . . . . . . . . . . .....C. palustris L. var. oryzetorum (Petrov) Lansdown 
4b. Bracts as long as but narrower than ripe fruits; leaf venation complex ..... C. fuscicarpa Lansdown

5a. Fruits widest in upper half, tapering from above midpoint to base. . . . . . . . . . . . 6

5b. Fruits widest at or near middle . . . . . . . 7

6a. Bracts lacking; leaves 1- to 3-veined........ . . . . . . . . . japonica Engelmann ex Hegelmaier

6b. Bracts present; leaves 1- to many-veined ..... $\ldots \ldots \ldots \ldots \ldots \ldots$. . palustris $\mathrm{L}$.

7a. Fruits winged only at apex... C. glareosa Lansdown

7b. Fruits winged all around $\ldots \ldots \ldots \ldots \ldots$

8a. Bracts lacking . . . . . . . . . . . . . 9

8b. Bracts present ................

9a. Fruits less than $1 \mathrm{~mm}$ long; some fruits with pedicels more than $1 \mathrm{~mm}$............. .......... C. deflexa A. Braun ex Hegelmaier

9b. Fruits more than $2 \mathrm{~mm}$ long; subsessile or with pedicels less than $1 \mathrm{~mm} \ldots \ldots \ldots \ldots \ldots$

10a. All leaves with only one vein, leaves lingulate. . .................. hermaphroditica $\mathrm{L}$.

10b. Leaves with 3 to many veins, with blade and petiole......... wightiana Wallich in Wight

11a. Bracts less than $0.5 \mathrm{~mm}$ long . . . . . . . . . . $\ldots \ldots \ldots \ldots \ldots \ldots$. raveniana Lansdown

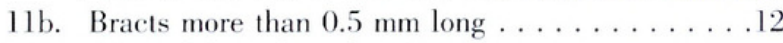

12a. Wing of fruits less than $1 \mathrm{~mm} \ldots \ldots \ldots \ldots$ $\ldots \ldots \ldots \ldots \ldots$. fuscicarpa Lansdown

12b. Wing of fruits more than $1 \mathrm{~mm} \ldots \ldots \ldots \ldots$ ........... fehmedianii Majeed Kak \& Javeid

1. Callitriche fuscicarpa Lansdown, sp. nov. TYPE: Nepal. Tamur Valley, Walungchung Gola, in shallow pond, 19 July 1956, J. D. A. Stainton 1045 (holotype, BM). Figure 1B.

Ab omnibus Callitriches speciebus Asiae fructu maturo rubribrunneo, circa omnino anguste alato, bracteis parvis praesentibus, stylis persistentibus differt.

Flowering plants submerged or with floating rosettes. Submerged leaves \pm lingulate, $6-9.7 \times 0.5-0.8 \mathrm{~mm}$; those toward or at the surface expanded, spathulate with petiole longer than blade, blade $3.2-5.2 \times 2.3-$ $4.2 \mathrm{~mm}$, petiole $2.9-5 \mathrm{~mm}$ long; venation complex, characterized by primary and secondary veins, plus additional sometimes branched loops and anastomosing veins outside the secondary veins. Flowers solitary in axils or occasionally 2 carpellate flowers opposed by a staminate flower; bracts persistent $(0.80-) 0.7-1.1 \mathrm{~mm}$. Filaments (0.6-)1.8-2.3 mm, \pm straight; anthers 0.3 $\times 0.3 \mathrm{~mm}$; pollen $20-24 \times 15-20 \mu \mathrm{m}$, yellow; styles persistent, erect to slightly spreading, $0.7-1.2 \mathrm{~mm}$. Fruits $0.7-1.1 \times 0.7-1 \mathrm{~mm}$, as long as or slightly longer than wide, dark brown becoming reddish brown, with faint reticulate pattern, resembling that of fruits of Callitriche palustris; subsessile or on pedicel less than $1 \mathrm{~mm}$; wing poorly developed or up to $0.08 \mathrm{~mm}$ at the apex and side.

Callitriche fuscicarpa differs from all species of Callitriche in Asia by the fruits being reddish brown to dark brown when ripe and narrowly winged all round, by the presence of small bracts, and by the persistent styles.

Distribution and habitat. I have found only very few specimens of Callitriche fuscicarpa; these would suggest that it is rare, although widely distributed, occurring between 1800 and $3500 \mathrm{~m}$ altitude in the Himalayas, in Uttaranchal Province in India and Nepal, east to Yunnan Province in China, with a single specimen from Hokkaido in Japan. There is no useful information on the habitat of this species.

Etymology. The epithet fuscicarpa refers to the brown fruits.

Paratypes. CHINA. Yunnan Prov: Col de Lo-pinchan, "Lan Kong," J. M.Delavay s.n. (P); J. M. Delavay 3279 (P): E flank of the Lichiang Range, G. Forrest 22575 (E, K, P): sine loc, D. W. Liu 7139 (MO, NAS). INDIA. Uttaranchal, small lake above Ramri, J. F. Duthie 4019 (K, MICH). JAPAN. Hokkaido: Kushiro River, Faurie 8696 (P).

2. Callitriche glareosa Lansdown, sp. nov. TYPE: Bhutan. Thimpu Distr.: Daga-La on the N side of Lawgu, in wet gravelly hollows between rocks in very wet moorland, $4400 \mathrm{~m}$, Sep. 1990, J. R. I. Wood 7321 (holotype, E). Figure 1C.

A Callitriche terrestri fructu solum ad apicem alato, a $C$. japonica fructu in medio latissimo, a $C$. raveniana bracteis absentibus differt.

Plants terrestrial. Leaves spathulate; venation simple, generally with 1 primary and a pair of secondary veins. Flowers solitary, most frequently a carpellate flower opposed by a staminate flower; bracts lacking. Filaments straight, up to $0.5 \mathrm{~mm}$; anthers $0.2 \times 0.2 \mathrm{~mm}$; pollen yellow, $22-26 \times 19-$ $23 \mu \mathrm{m}$; styles up to $0.6 \mathrm{~mm}$, persistent, reflexed, but not appressed to side of fruits. Fruits $0.6-0.7 \times 0.8-$ $1 \mathrm{~mm}$, slightly wider than high, black when ripe, faintly reticulate, expanded toward base, but not strumose; subsessile or with pedicel up to $0.6 \mathrm{~mm}$; wing apical only $0.05-0.1 \mathrm{~mm}$ wide at apex.

Callitriche glareosa differs from $C$. terrestris by the fruits being winged only at the apex, from $C$. japonica by the fruits being widest in the middle, and from $C$. raveniana by the lack of bracts.

Distribution and habitat. I have seen only two specimens of Callitriche glareosa, the type specimen from Bhutan and one from Tibet. The type was collected from above $4000 \mathrm{~m}$, and it is likely that the record from Tibet will have been made at a similarly high altitude.

Etymology. The epithet glareosa refers to the gravel habitat noted for the type collection. 


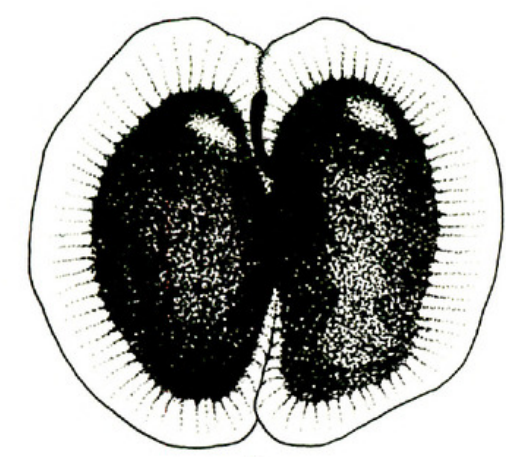

A

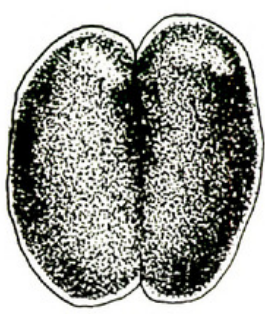

B

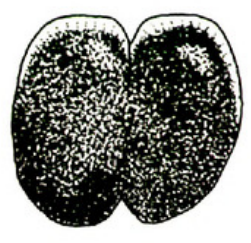

C

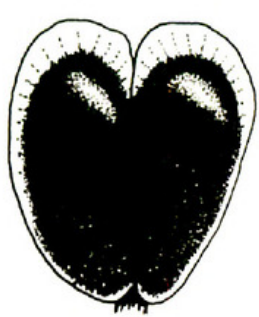

D

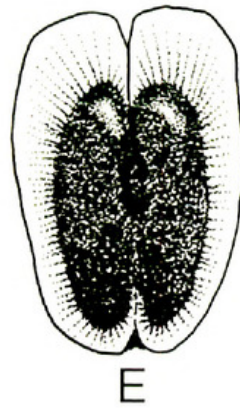

E

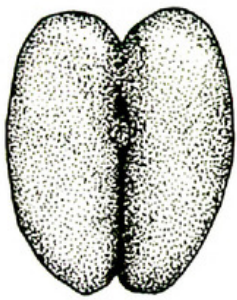

F

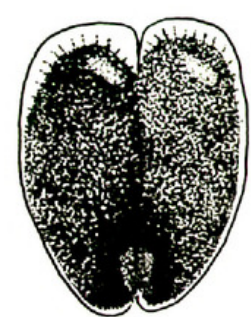

G

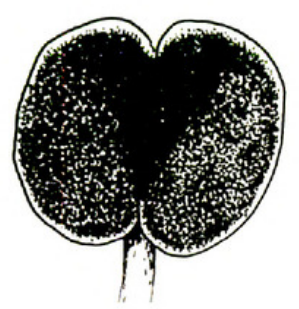

$\mathrm{H}$

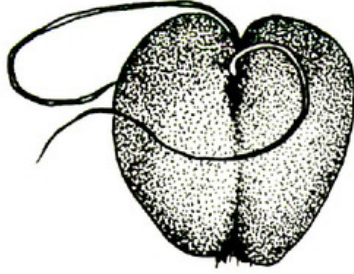

I

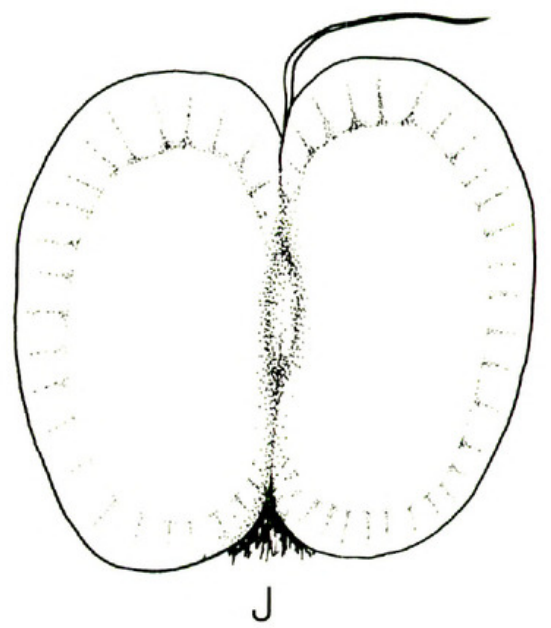

Figure 1. A-J. Fruits of Asian Callitriche. - A. C. fehmedianii (drawn from Ducloux 5/7. P). - B. C. fuscicarpa (drawn from J. M. Delaray s.n., P). - C. C. glareosa (drawn from J. R. I. Wood 732/. E). -D. C. palustris var. elegans (drawn from Hu \& Bu 21976, K). - E. C. palustris var. megalata (drawn from A. Kiss s.n. MIC.H). - F. C. palustris var. or zetorum (drawn from II. F. Hance 4321, P). —C. C. palustris var. strumosa (drawn from W. Meiner 6601/. L). - II. C. rateniana (drawn from C.-I. Peng 13917. HAST). - I. C. subanceps (drawn from I. Komaron s.n.. K). - J. C. wightiana (drawn from R. Wight 7008. K). 
Paratype. CHINA. Xizang Zizhiqu (Tibet): sin coll. (PE 0901712).

3. Callitriche japonica Engelmann ex Hegelmaier, Verh. Bot. Ver. Prov. Brandenburg 10: 113-114. 1868. TYPE: Japan. Hokkaido: Hakodate [Hakodadi], C. Wright s.n. in U.S.N. Pacific Exped. 1853-1856 (holotype, MO 1913973; isotype, K).

Callitriche nana B. C. Ho \& G. T. P. Vo, Floribunda Sisipan 2(3): 59. 2003. Syn. nov. TYPE: W Java. W. J. De Wilde, Wiriadinata, Rugayah \& P. Hovenkamp 22275 (holotype, BO not seen; isotypes, K. L, P).

Plants terrestrial. Leaves expanded, shiny, blades $1.5-4.5 \times 1-2.5 \mathrm{~mm}$, petiole $1-1.5 \mathrm{~mm}$ long: venation simple, generally limited to one primary and a pair of secondary veins with occasional short veins arising within and outside the secondary veins. Flowers solitary, most frequently a pair of axils with a carpellate flower opposed by a staminate flower: bracts lacking. Filaments $0.2-0.4 \mathrm{~mm}$, \pm straight; anthers $0.2 \times 0.2 \mathrm{~mm}$; pollen $13 \times 15.4 \mu \mathrm{m}$; style $0.28-0.33 \mathrm{~mm}$, \pm straight. Fruits $0.7-1 \mathrm{~mm} \operatorname{long} \times$ $0.7-1 \mathrm{~mm}$ wide, brown to blackish when ripe, tapering toward the base; wing $0.05-0.1 \mathrm{~mm}$ at the apex, $0.03-$ $0.08 \mathrm{~mm}$ at the side.

Callitriche japonica differs from other Callitriche species in Asia in having the fruits winged all around and tapering from the apex toward the base and no bracts.

Backer (1954) recorded three forms of Callitriche palustris, of which the terrestrial form was represented by material collected by van Steenis from Tjibodas [Cibodas]. West Java; the other two forms were associated with material from Papua New Guinea. In 2002, further material was collected from the Botanical Garden at Cibodas and described as a new species, C. nana B. C. Ho \& G. T. P. Vo. Both the van Steenis material and isotypes of $C$. nana in $\mathrm{K}$ and $\mathrm{L}$. represent typical $C$. japonica and so the name $C$. nana is reduced here to synonymy with $C$. japonica.

Distribution and habitat. Callitriche japonica occurs in central and southern Japan (Yamazaki, 1993), as well as China from Fujian, Jiangxi, and Taiwan. There is herbarium material from northern Thailand, West Bengal (India), and Java (Indonesia). The last two records are from botanical gardens and could represent established aliens; however, more information is needed to establish the western and southern extremes of its range. C. japonica appears to be associated with disturbed ground and roads or tracks, in humid locations often in partial shade.

Additional specimens examined. CHINA. Fujian [Fokien] Prov.: sine coll. 2700 (K). Jiangxi [Kiangsi] Prov.:
(PE 0990315). INDIA. W. Bengal: Darjeeling Dist., Darjeeling, Lloyd Bot. Gardens, D. G. Long, R. J. D. McBeath, H. J. Noltie, M. F. Watson ESIK 1047 (E). INDONESIA. Java: Tjibodas [Cibodas], S. J. van Ooststroom 13073 (L), J. F. Veldkamp 8616 (L), G. G. J. van Steenis s.n. (L). JAPAN. Hokkaido: L. Savatier 426 (P). Honshu: Shimoda, C. Wright s.n. (K); M. Hutoh 24811 (E, L, P). TAIW AN. Ilan Hsien, Pinglin, Shueide, C. $h$. Chen 3880 (HAST): Ilan Hsien, Tatung Hsiang, Y.-c. Kao 400 (HAST): Ilan Hsien, Fushan Bot. Garden, C.-I. Peng 13873, (HAST): Taipei Hsien, Shih-ting Hsiang, Fei-tsui-shui-ku, J.-c. Wang 11377 (HAST, TNU). THAILAND. Chang-mai, Lekong-yun [yuen] R. P. Courtois 25605 (P).

4. Callitriche palustris L., Sp. Pl. 2: 969. 1753. TYPE: "Habitat in Europae fossis paludibus," lowermost three specimens on sheet (lectotype, designated by Lansdown \& Jarvis (2004: 171), LINN 13.2).

Callitriche verna L., Fl. Suec. ed. 2: 2. 1755. TYPE: Uppermost three specimens on sheet (lectotype, designated by Lansdown \& Jarvis (2004: 171), LINN 13.2).

Plants submerged, with floating rosettes or on wet mud. Lingulate leaves linear to narrowly expanded, emarginate, with a single vein (4-) 5.6-9.7 $\times 0.5-$ $1.2 \mathrm{~mm}$; expanded leaves with blade elliptic to \pm orbicular 3.6-9.9(-10.3) × 1.2-4.3(-4.5) mm; most leaves have at least part of a tertiary vein, they generally also have additional veins arising from secondary veins either as loops rejoining adjacent secondary veins or as short slightly curved veins pointing \pm directly to blade margin.

Callitriche palustris occurs throughout much of the Northern Hemisphere but is generally restricted to high altitudes in the southern part of its range, from Iceland and Finland south to the Pyrenees (Lansdown, 2006, in press), east to Japan and Kamchatka in the Russian Far East. In North America it occurs from Greenland south to New Mexico (Fassett, 1951). It has also been recorded from Australia, where it may have been introduced (Aston, 1973).

Key to the V arieties of Callitriche palustris Found in Asia

la. Fruits winged only at apex or lacking, wing up to $1 \mathrm{~mm}$ wide. . . . . . . . . . . . . 2

1b. Fruits winged all around, wing at least $1 \mathrm{~mm}$ wide at apex .................

2a. Bracts caducous, styles and filaments to $1 \mathrm{~mm}$ long, caducous . . . . . . . . . . par. palustris

2b. Bracts persistent, styles to $1.7 \mathrm{~mm}$, filament to $2.7 \mathrm{~mm}$ long, persistent . . . . . . var. oryzetorum

3a. Wing at least $1.5 \mathrm{~mm}$ at apex and well developed at the base. . . . . . . . . . . . megalata

3b. Wing less than $1.5 \mathrm{~mm}$ at apex, very narrow at

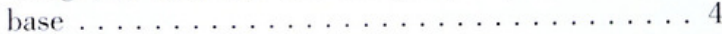

4a. Styles persistent, fruits slightly strumose. . var. elegans 4b. Styles caducous, fruits strongly strumose... var. strumosa 


\section{4a. Callitriche palustris L. var. palustris}

Callitriche fallax Petrov, Izv. Glavn. Bot. Sada S.S.S.R. 27: 358. 1928. Callitriche verna var. fallax (V. Petrov) Hara in Bol. Mag. Tokyo 49: 866. 1935. TYPE: Russia. Kamchatka Peninsula, V. L. Komarov, 2975 (hololype, LE, not seen).

Sarwar (1998) cites two specimens of Callitriche palustris in $\mathrm{K}$, both of which belong to the nominate variety. In addition, a single specimen in BM is cited as $C$. stagnalis. This specimen also belongs to $C$. palustris var. palustris. It has not been possible to confirm the identity of other specimens cited as $C$. stagnalis, and until they can be formally determined, only this species $C$. palustris can be confirmed as occurring in Pakistan.

In Asia, Callitriche palustris var. palustris occurs in Kashmir, Himachal Pradesh. and Sikkim in India and in Nepal and Bhutan, throughout China, north to Siberia and Kamchatka in Russia. South Korea. and east to Japan. The taxon is apparently absent from areas to the south of the Himalayas and China.

Additional specimens examined. BHUTAN. Upper Vo Chu Dist.: Tharizan Chu, I. W. J. Sinclair \& D. G. Long 5.38 (E). CHINA. Guangdong [Kwangtung] Prov.: Whampoa. T. Sampson 4.32 l (K. BM). Hong Kong: Lam Tsuen, N.T.. K. Y. Chan 14I4 (K). Jilin [Kirin] Prov.: O-muhsien. H. W. Kung 2186 (PE). Quinghai [Tsinghai] Prov.: Jimai [Gyümai| Ziang, Sainaniuda, Dari [Darlag] Xian, Huang He, T. N. Ho, B. Bartholomew \& V. Gilbert 1238 (K): Huangnan Zang Aut. Pref., Henan Mongol. Aul. Co., N of Henan Xian, Zêkog River, D. G. Long, C. Brictinell, R. J. D. UcBeath, E. J. Stranman, R. Steele, X. F. Lu, D.-S. Deng \& S.-R. Zhang 631 (E). Sichuan Prov.: Huang-chen-kuen, H. Smith 3994 (K): K. L. Chu 7929 (PE). Xizang Zizhiqu [Tibet]: T'sangpo Valley. Tammysu, F. Ludlou. G. Sherriff \& H. H. Ellio 14226 (K); Tungdo, Tsanpo Valley, Kongbo, F. Ludlow, G. Sherriff \& G. Taylor 451.5 (K); Kulu Phu Chu. Paka, F. Ludlow, G. Sherriff \& G. Taylor 5945 (K): Tsangpo Valley, Tsela, F. Ludlow, G. Sherriff \& G. Taylor 5486 (K): Je [Pasum Lake] F. Ludlow, G. Sherriff \& H. H. Elliol 14.1.33 (K. BM). Zhejiang [Chekiang] Prov.: Sungyang, H. W. Kung s.n. (PE). INDIA. Himachal Pradesh: between Sangla and Rakcham, N. C. Nair 34302 (L). Sikkim: S of Dhzongri. Phedang, D. G. Long, R. J. D. McBeath, H. J. Noltie \& V. F. Watson ESK 722 (E). JAPAN. Honshu: Aomori Prov.. U. J. Faurie s.n. (P): Kyoto Pref., Kamiike, Ikejiri. Umaji-cho. Kameoka-shi, S. Tsugara 15824 (MO). Hokkaido: Sapparo, Yezo, S. Arimoto s.n. (MO). NEPAL. Phagune Dhuin, J. D. A. Stainton, V. R. Sykes \& L. Williams 4798 (K. B M): Everest region, Lobuche, Khumba glacier, G. Viehe s.n. (K, BM): Ghalike Pahar, J. D. A. Stainton, V. R. Sykes \& L. Williams 3764 (K. BM): Langlang, O. Polunin 521 (BM): Chilime Kharka, O. Polunin 1473 (BM); Jumla, O. Polunin, V. R. Sykes \& L. Williams 913 (BM, E); Longponga, J. de Hass 3018 (L): Nyimagawa Plain. J. de Hass 3070 (L). PAKISTAN. Kashmir: Kishinsar, O. Polunin $56 / 671$ (BM): Liddar Valley, Badzulkod nala, J. F. Duthie 1.34l4 (K): Yamharu Pass, J. F. Duthie 13573 (K). RUSSIA. Kamchatka oblast: Schapino Village, River Kamchatka, I. Komarot 2975 (LE). East Siberia, Tomskaya oblast: A. V. Polozhii \&. S. N. Viginja s.n. (MO). SOUTH KOREA. V. Faurie 1794 (K, BM. E).
TAIW AN. Ilan Hsien, Tatung Hsiang, Ssuchi Forest Road, C.-I. Huang 90995 (HAST); Hsinchu Hsien, Chienshih Ilsiang. Yuanjanghu N.R., C.-I. Peng, $15 / 6.3$ (HAST).

4b. Callitriche palustris L. var. elegans (Petrov) Y. L. Chang, Fl. Pl. Herb. Chin. Bor.-Orient. 6: 53. 1977. Basionym: C. elegans Petrov, Bull. Jard. Bot. Princ. URSS 27: 360. 1928. TYPE: Russia. "Austro-Usuriensis ad fl. Sutshan prope pag. Vladimiro-Alexandovsk," 4 July 1913, A. Bulavkina s.n. (holotype, LE not seen). Figure ID.

Callitriche bengalensis Petrov, Bull. Jard. Bot. Princ. URSS 27: 358. 1928. Syn. nov. TYPE: Bangladesh. Griffith 2445 (holotype, I.E).

Generally one carpellate and one staminate flower in one of a pair of axils opposed by a single carpellate flower in the other, very occasionally 2 carpellate flowers and a staminate flower in a single axil; bracts persistent, 0.8-1.2 mm, falcate. Filaments \pm straight, caducous, rarely visible in axils below shoot apices, up to $2.2 \mathrm{~mm}$; anthers $0.4 \times 0.3 \mathrm{~mm}$; pollen yellow. ovoid-ellipsoid, $21-26 \times 17-25 \mu \mathrm{m}$; styles erect to slightly spreading, up to $1.5 \mathrm{~mm}$ long. Fruits $1-1.4 \times$ $0.7-1.1 \mathrm{~mm}$, widest above the middle, slightly strumose, black when ripe, mericarps sharply reticulate, the reliculations appearing \pm clearly in vertical rows, wing $1-1.5 \mathrm{~mm}$ wide toward apex.

Callitriche palustris var. elegans differs from all other varieties of $C$. palustris in both the bracts and the styles being persistent and in the wing being $1-$ $1.5 \mathrm{~mm}$ wide at the apex of the fruits and \pm lacking from the base.

Distribution and habitat. Callitriche palustris var. elegans occurs from Bangladesh to the Baikal region in Russian Siberia, east to Sakhalin Island (Shishkin. 1974), south through Japan to the Ryukyu Islands as well as Jiangsi, Jilin, and Hong Kong in China. The only information available refers to Callitriche palustris var. elegans growing in nutrient-rich drainage ditches.

Additional specimens examined. CHINA. Hong Kong: Lam Tsuen, N.T., Hu \& Bu 21976 (K). Jilin (Kirin) Prov.: Kiriňeňsig Prov., Jehitu-deňsa Valley, betw. Ninuolà \& Omōdo, V. Komarov 1033 (K. BM). JAPAN. Honshu: Settsu. Nakayamaderea in Kawanobegun, M. Togasi TSM 795 (E): Sellsu, Takarazuka, Hondo. T. Makoto NSM 498 (L. MO). Ryukyu Islands: Amami-oshi m. Nase City, Uraami. Ryukyus, S. Htusima \& S. Sako 23876 (L). RUSSIA. Sutagi [Sungagi] River, R. K. Maak s.n. (LE); Sachalin oblast: Ins. Sachalin, Augustinowicz s.n. (LE): Zabaikalskava oblast: Shilka River, Ust Kara, Striutinstii \& Blagovorusheno s.n. (LE).

4e. Callitriche palustris I.. var. megalata Lansdown, var. nov. TYPE: Russia. Eastern Siberia. 
Primorskaja Distr., Nikolsk-Ussurisk, 20 Aug. 1917, Á. Kiss s.n. (holotype, MICH). Figure 1E.

Ab omnibus aliis Callitriches palustris varietatibus ala ad fructus apicem latiore quam $1.5 \mathrm{~mm}$ differt.

Generally one carpellate and one staminate flower in each axil, the staminate flower very briefly caducous and generally missing from axils below shoot apex; bracts caducous, ovoid, rounded, $0.2-$ $1.2 \mathrm{~mm}$. Filaments erect to gently curved, 1.5$1.8 \mathrm{~mm}$; anthers $0.45 \times 0.51 \mathrm{~mm}$; pollen $21-25$ $\times$ 19-20 $\mu \mathrm{m}$, yellow, strongly ornamented; styles \pm erect, $0.2-0.8 \mathrm{~mm}$. Fruits $1.2-1.4 \times 0.9-1 \mathrm{~mm}$. higher than wide, dark with pale wing; subsessile, very broadly winged, mainly at apex and base; wing 2-2.6 $\mathrm{mm}$ wide at apex, $1.3-1.8 \mathrm{~mm}$ wide at side.

Callitriche palustris var. megalata differs from all other varieties of $C$. palustris in having the wing more than $1.5 \mathrm{~mm}$ wide at the apex of the fruits.

The description is based only on the type specimen. However, the characters of the wing are sufficiently different that $\mathrm{I}$ have no hesitation in describing it as a new variety of Callitriche palustris.

4d. Callitriche palustris L. var. oryzelorum (Petrov) Lansdown, comb. et stat. nov. Basionym: C. oryzetorum Petrov, Bull. Jard. Bot. Princ. URSS 27: 358. 1928. TYPE: [China.] "In oryzetis cantonensibus," Mar. 1867, H. F. Hance 4.321 (holotype, LE; isotypes, K, P). Figure 1F.

Generally, one carpellate and one staminate flower in each axil, very occasionally 2 carpellate flowers and a staminate flower in one axil; bracts persistent, $0.6-0.9(-1) \mathrm{mm}$, broadly ovoid. Filaments straight. $1.6-2.7 \mathrm{~mm}$; anthers $0.4-0.5 \times 0.3-0.4 \mathrm{~mm}$; styles erect to spreading, less than $1.7 \mathrm{~mm}$ long. Fruits $0.7-$ $1 \times 0.6-0.8 \mathrm{~mm}$, widest near the middle, ripe fruits brown, smooth; wing lacking, or less than $0.1 \mathrm{~mm}$ at apex, becoming narrower down the sides.

Callitriche palustris var. oryzetorum differs from all other varieties of $C$. palustris in the very large bracts and the persistent styles.

Distribution and habitat. Thought for a long time to be endemic to Guangdong Province, Callitriche palustris var. oryzetorum occurs mainly in southern China, from Yunnan through Fujian and Guangdong Provinces to Taiwan, and there is a single specimen in $\mathrm{K}$ from Japan. The only information available describes $C$. palustris var. oryzetorum as growing in a river and in ricefields.

Additional specimens examined. CHINA. Fujian [Fukien] Prov.: Peiyueang Hsiang, H. Migo s.n. (PE). Yumnan
Prov.: Lichiang, near Ngu Leh Keh, C. Schneider 1996 (K). Zhejiang [Chekiang] Prov.: $\sin$ coll. (PE 1514). JAPAN. Kyushu: Kogakura Reservoir, N. Mackawa 9/39 (K). Taiwan: [Shinchiku-shu, Toyen], T. Tanaka \& Y. Shimada 1.3530 (E, MICH, MO, PE).

4e. Callitriche palustris var. strumosa Lansdown, var. nov. TYPE: [Indonesia.] W Sumatra, Pesisir Selatan Kerintji Dist., Kerintji, Banto, Rawah Banto, marsh s.d., W. Meiner 66014 (L). Figure 1G.

Ab omnibus aliis Callitriches palustris varietatibus fructus partis inferioris margine interiore in orcam tumido, a $C$. peploide fructu ab apice ad basin alato differt.

Generally one carpellate and one staminate flower in one of a pair of axils opposed by a single carpellate flower in the other; bracts persistent, 0.4-1 mm, falcate. Filaments \pm straight, less than $0.5 \mathrm{~mm}$, obscured by carpellate flowers; anthers much reduced, possibly aborted; pollen yellow; styles erect, \pm widely spreading, $0.8-1.2 \mathrm{~mm}$. Fruits $1-1.1 \times$ $0.8-1 \mathrm{~mm}$, widest above the middle, strongly strumose to extent that base of each mericarp is twisted, black when ripe, mericarps sharply reticulate, reticulations appearing \pm clearly in vertical rows; wing mainly toward apex, but very narrow along sides, $0.1-0.2 \mathrm{~mm}$ wide at the apex and $0.03-0.07 \mathrm{~mm}$ wide on the side.

Callitriche palustris var. strumosa differs from all other varieties of $C$. palustris in the inner margin of the lower part of the fruits being swollen into a ridge and from $C$. peploides in the fruits being winged from apex to base.

Distribution and habital. This variety is described from only two specimens, both in L. Apart from the obligate terrestrial taxa, Callitriche is normally represented in the tropics only at high altitude. Unusually one of the specimens cited here appears to have been collected in pools in a marsh on a coastal island, at sea level. No material of this variety is represented in collections from Irian Jaya or Papua New Guinea. With such limited material, it is difficult to explain its distribution. It is of note that Backer (1954: 252) refers to Callitriche sp. "mentioned by Kurz (Nat. Tijd. N.I. 27, 1864, 167) from clear streams in the Menumbung Hills, Banka Island" and expresses doubt about the record "firstly because Kurz's material was sterile and has not been traced in the herbarium and secondly because all specimens of Callitriche hitherto found in the Malaysian tropics occur at much higher altitudes." Banka Island lies off the east coast of southern Sumatra and between the Iwo locations from which herbarium specimens of $C$. palustris var. strumosa have been seen. Callitriche 
palustris var. strumosa is the only Callitriche recorded from low altitudes in the tropics, apart from obligate terrestrial species such as $C$. peploides. It seems possible that the records discussed by Backer (1954) refer to this taxon.

Paralype. |MALAYsIA.| Sabah, [Manukan?] Island, A. J. G. Kostermans s.n. (L).

5. Callitriche raveniana Lansdown, sp. nov. TYPE: [Taiwan.] Taipei Hsien, Kueishan, Pei-Shih-Hsi, border of rocky river bed, $100 \mathrm{~m}, 16 \mathrm{Apr}$. 1991, C.-I. Peng 1.3917 (holotype, HAST). Figure IH.

Ab aliis Callitriches speciebus terrestrialibus Asiae bracteis minutis praesentibus differt.

Plants terrestrial. Leaves expanded, \pm spathulate, blade $2-2.5 \times 0.5-0.8 \mathrm{~mm}$, petiole $1.3-1.5 \mathrm{~mm}$; venation simple, usually limited to one primary and a pair of secondary veins with occasionally a few branches arising from secondary veins. Generally one carpellate and one staminate flower in each axil. occasionally only one solitary carpellate flower; bracts persistent, $0.2-0.3 \mathrm{~mm}$. Filaments $0.2-0.3 \mathrm{~mm}$ : anthers very reduced, $0.2 \times 0.2 \mathrm{~mm}$; pollen spherical to ellipsoid, yellow, $20 \times 18-20 \mu \mathrm{m}$; styles 0.2 $0.3 \mathrm{~mm}$. Fruits wider than high, 0.6-0.9 $\times 0.8-$ $1.3 \mathrm{~mm}$; subsessile to shortly pedunculate; winged throughout, wider at the apex, 0.07-0.1 mm wide at apex, $0.05-0.08 \mathrm{~mm}$ wide at side.

Callitriche raveniana differs from other terrestrial species of Callitriche in Asia by the presence of minute bracts.

Distribution and habitat. Both specimens of $C$. raveniana were collected from broad-leaved forest in Taiwan; one collection from a stream bed and the other from roadside.

Etymology. Named in honor of Dr. Peter H. Raven, President of the Missouri Botanical Garden.

This description is based on two specimens, both from Taiwan.

Paratype. CHINA. Taiwan: Taipei Co., Wulai Hsiang, Hsiaoyi, Tunghou stream. S.-c. Liu, C.-h. Chen 251 (II AST. TNU).

6. Callitriche wightiana Wallich in Wight \& Arnotl 1834, Prodr. Fl. Ind. Orient: 339. 1834. TYPE: India. "Neelgherries" [Nilgiri Hills] s.d., $R$. Wight 7008 (lectotype, designated here, K |Hb. Wallich], isotypes, CGE, E, K). Figure IJ.

Plants terrestrial or in shallow water. leaves expanded, venation very complex, with many subsidiary veins arising from primary vein, within secondary veins and either anastomosing, rejoining secondary vein or splitting into many minor, muchbranched veins, many veins also arise on outside of secondary veins and either rejoin this or anastomose. Flowers solitary, most frequently a pair of axils with a carpellate flower opposed by a staminate flower; bracts lacking. Filaments \pm erect, less than $2.5 \mathrm{~mm}$; anthers higher than wide, $0.4 \times 0.4 \mathrm{~mm}$; pollen yellow, strongly ornamented, $20 \times 18-20 \mu \mathrm{m}$; styles erect or slightly spreading, less than $2 \mathrm{~mm}$. Fruits distinctly wider than high, $1.8-2.3 \times 1.4-2 \mathrm{~mm}$; very broadly winged all round, wing very poorly differenliated in dried material, $0.3-0.4 \mathrm{~mm}$ wide at apex and sides.

Callitriche wightiana differs from all other Callitriche in the region by the fruits broadly winged all around, very complex venation, and lack of bracts. Although superficially similar to $C$. fehmedianii, herbarium material of $C$. wightiana can be separated by the uniform appearance of the fruits, whereas those of $C$. fehmedianii show a clear distinction between the wing and the main body of the mericarp. It also appears likely that $C$. wightiana grows mainly as a terrestrial plant in damp, forested habitats or in shallow water, whereas $C$. fehmedianii often grows in relatively deep water.

The protologue cites the type as "Wall.! L. under n. 7008; Wight! rat. n. 1095. C. verna var. vulgaris, Wall.! I. n. 7008 - Neelgherries." There is a specimen in the Wallich Herbarium in $\mathrm{K}$ that is undoubtedly the material on which the name is based and is designated here as the lectolype. From notes made on the various sheets, it appears that this is a part of a specimen labeled "Nilghirry Hills (Neelgherries), [undated] Wall, I. 7008 - W.C. 1095 Callitriche wightiana" in $\mathrm{K}$ and apparently the same as material labeled "Herb. Wight. propr. 11. 1095, Callitriche wightiana Wall. L.n. 7008, Neelgherries, Peninsula Ind. orientalis" in E.

Distribution and habitat. Callitriche wightiana appears to have a limited distribution, with records from Sri Lanka and from Tamil Nadu in southeast India. It appears to occur mainly among mosses or in small pools in woodland.

Additional specimens examined. INDIA. Tamil Nadu [Madras]: Kodaikanal Dist., Berijam, Dindigul, K. $M$. Mathew \& M. Charles RHT 46005 (K). SRI LANKA. Sin coll. 36.36 (BM, CCE, P); Central Prov., Nuwara Eliya Dist., Ilorton Plains, Farr Inn, N. Balakrishnan NBK 421 (K, MO); Dieter's Plot P24. N Entrance. Horton Plains, F. R. Fosberg \& D. Mueller-Dombois 50039 (K, MO): Nuwara-eliya Dist.. Ilakgala Bot. Carden, A. H. M. Jayasuriva \& D. S. A. IIjesundara $3.36 /(\mathrm{MO})$. 
Acknowledgments. I am deeply grateful for the help that Peter Raven (MO) has given to me with access to specimens and the literature and which has made this study possible. I am also very grateful to Mike Gilbert $(\mathrm{K})$ for all his help and hospitality. I would like to thank Eona Aitken (E), Paul Berry (MICH), Dave Boufford (HUH), Olga Cherneva (LE), Aljos Farjon (K), K. N. Ganeshaiah, Kanchi Ghandi (HUH), Peter Hoch (MO), Wout Holverda (L), Hongwen Huang (HIB), Rudolf Kamelin (LE), John Kress (NMNH), Chen-Meng Kuo (TAI), Jianqiang Li (HIB), G. S. Mohan, Gina Murrell (CGE), Ching-I Peng (HAST), Tim Rich (NMW), Tony Reznicek (MICH), Tatyana Shulkina (LE), Nick Turland (MO), Roy Vickery (BM), Jenn-Che Wang (TNU), Aleck T. Y. Yang (TNM), Sheng-Zehn Yang (PPI), and the late Guanghua Zhu (MO) for their help with organizing access to material as well as helping me with many other issues. I am very grateful to Dr. Sachiko Nishida for seeking out information on Callitriche japonica for me. I would also like to thank Philip Oswald for providing me with the Latin diagnoses, John Bruinsma for translating Dr. Schotsman's letter, Bruce Ponman (MO) for translating Hegelmaier's account of $C$. japonica, and Maria Vorontsova (K) for transliterating and translating many of the Russian and Cyrillic herbarium labels. I would like to thank Norton Miller and Surrey Jacobs for their contribution as referees and Victoria Hollowell for her help with editing.

\section{Literature Cited}

Aston, H. I. 1973. Aquatic Plants of Australia. Melbourne Univ.
Backer, C. A. 1954. Callitrichaceae. Pp. 251-252 in C. G. G. van Steenis (editor), Flora Malesiana. Noordhoff-Kolff N.V., Jakarta.

Cheng, M. \& T.-L. Ming. 1980. Flora Reipublicae Popularis Sinicae 45: 11-13. Science Press, Beijing.

Cook, C. D. K. 1996. Aquatic and Wetland Plants of India: A Reference Book and Identification Manual for the Vascular Plants Found in Permanent or Seasonal Fresh Water in the Subcontinent of India South of the Himalayas. Oxford Univ. Press, Oxford.

Fassett, N. C. 1951. Callitriche in the New World. Rhodora 53: 137-155; 161-182.

Kak, A. M. \& G. N. Javeid. 1982. A revision of the genus Callitriche L. in the north western Himalayas. J. Bombay Nat. Hist. Soc. 79: 167-172.

Lansdown, R. V. 2006. Notes on the water-starworts (Callitriche) recorded in Europe. Watsonia 26: 105-120. . In press. Water-starworts (Callitriche) of Europe. B.S.B.I Handbook No. 11. B.S.B.I., London.

\& C. E. Jarvis. 2004. Linnaean names in Callitriche L. (Callitrichaceae) and their typification. Taxon 53: $169-172$.

Larsen, K. 2000. Callitrichaceae. In T. Santisuk \& K. Larsen (editors), Flora of Thailand. Vol. 7: 251-252.

Merrill, E. D. \& L. M. Perry. 1941. Plantae Papuanae Archboldianae VI. J. Arnold Arbor. 22: 253-270.

Sarwar, G. R. 1998. Callitrichaceae. In S. I. Ali \& M. Qaiser (editors), Flora of Pakistan. No. 201. Dept. Bot. Univ., Karachi.

Schotsman, H. D. 1985. Une nouvelle espèce de Callitriche (Callitrichaceae) de Papoua-Nouvelle-Guinée: Callitriche cycloptera Schotsm. Bull. Mus. Natl. Hist. Nat., B, Adansonia 7: 115-121.

Shishkin, B. K. (editor). 1974, Flora of the U.S.S.R. Volume XIV. Geranialies, Sapindales, Rhamnales. Israel program for Scientific Translations, Jerusalem.

Yamazaki, T. 1993. Callitrichaceae: 323. In K. Iwatsuki, T. Yamazaki, D. E. Boufford \& H. Ohba (editors), Flora of Japan. Vol. IIIa. Angiospermae Dicotyledoneae Sympetalae, Kodansha, Tokyo. 

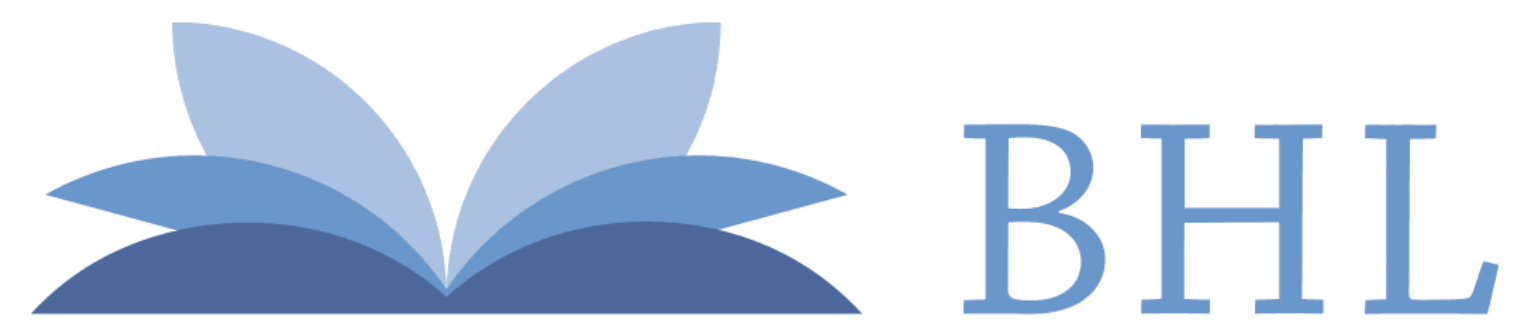

\section{Biodiversity Heritage Library}

Lansdown, R V. 2006. "The genus Callitriche (Callitrichaceae) in Asia." Novon a journal of botanical nomenclature from the Missouri Botanical Garden 16, 354-361.

View This Item Online: https://www.biodiversitylibrary.org/item/41804

Permalink: https://www.biodiversitylibrary.org/partpdf/37315

\section{Holding Institution}

Missouri Botanical Garden, Peter H. Raven Library

\section{Sponsored by}

Missouri Botanical Garden

\section{Copyright \& Reuse}

Copyright Status: In copyright. Digitized with the permission of the rights holder.

License: http://creativecommons.org/licenses/by-nc-sa/3.0/

Rights: https://biodiversitylibrary.org/permissions

This document was created from content at the Biodiversity Heritage Library, the world's largest open access digital library for biodiversity literature and archives. Visit BHL at https://www.biodiversitylibrary.org. 